\title{
A MORPHOMETRIC STUDY OF THE THYROID GLAND IN HUMAN
} CADAVERS

\author{
Shobha Gaikwad ${ }^{*}$, Rajani Joshi ${ }^{2}$. \\ ${ }^{{ }^{*} 1}$ Assistant Professor, Department of Anatomy, Seth G S Medical College and KEM Hospital, Parel, \\ Mumbai, Maharashtra, India. \\ 2 Professor and Head, Department of Anatomy, Government Medical College, Miraj, Dist. Sangli, \\ Maharashtra, India.
}

\section{ABSTRACT}

Introduction: The size and shape of the thyroid gland may alter remarkably with age, gender, physiological condition, race, and geographical location. Thus the knowledge of the various parameters and position of thyroid gland are important while doing surgeries on thyroid gland as well as during tracheostomy in emergency condition.

Materials and methods: The study was structured to investigate the morphometric as well as topographical features of the thyroid gland in 100 cadavers (58 males and 42 females) from Maharashtrian population

Result: The right lobe of the thyroid gland was found to be larger than the left lobe. An average length and width of isthmus were $1.38 \mathrm{~cm}$ and $1.02 \mathrm{~cm}$. An average weight of thyroid gland was 14.5 grams. The $P$ value was 0.00 it shows that gender wise difference in different parameters was highly significant. Most commonly the isthmus was lying opposite to $1^{\text {st }} 2^{\text {nd }}$ and $3^{\text {rd }}$ tracheal rings. Gender wise difference in position of isthmus was statistically insignificant.

Conclusion: This study highlights the various parameters of thyroid gland as well as shows the gender wise difference in it.

KEY WORDS: weight of thyroid gland, position of isthmus, length of right lobe, width of isthmus.

Address for Correspondence: Dr Shobha Gaikwad, Assistant Professor, Department of Anatomy, $2^{\text {nd }}$ floor, Seth G S Medical College and KEM Hospital, Parel, Mumbai, Maharashtra, India -400012. Mobile No. 8652868522, E-Mail: shobhagaikwadjadhav@gmail.com

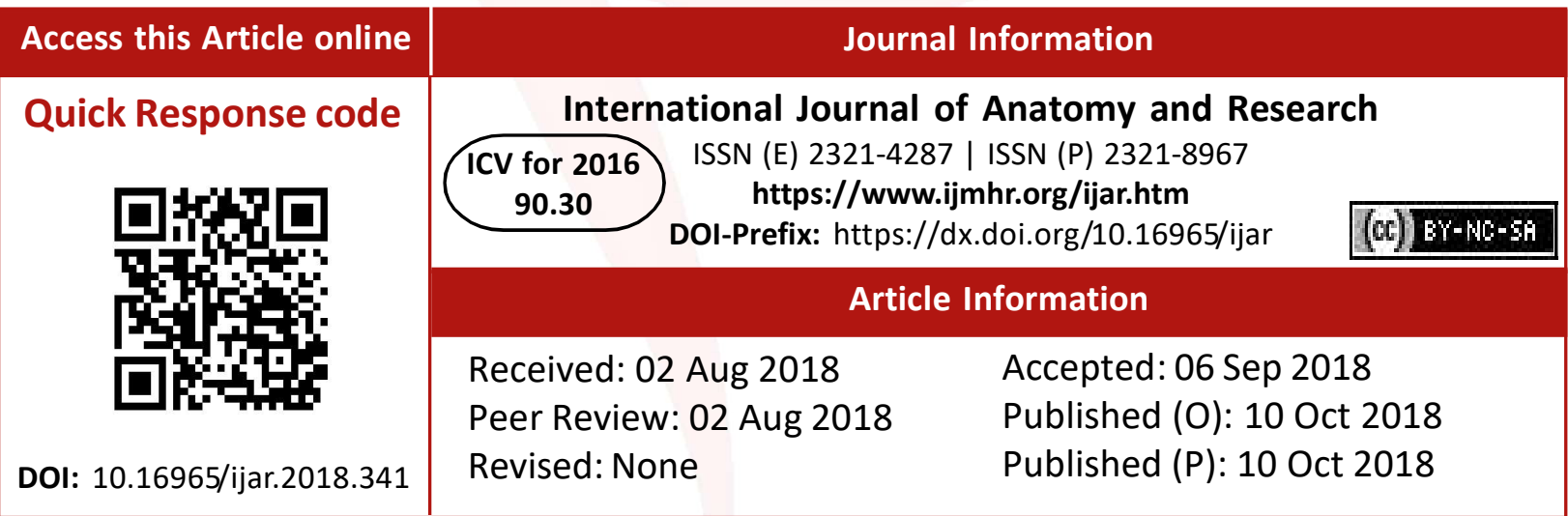

\section{INTRODUCTION}

The thyroid gland is an important endocrine gland in human body, which is situated anteriorly in the lower part of the neck .It consists of two symmetrical lobes connected by an isthmus which is $\mathrm{H}$ shaped and lies against $2^{\text {nd }}, 3^{\text {rd }}, 4^{\text {th }}$ tracheal rings. It is a highly vascular gland. It is the first endocrine organ to evolve in the vertebrates [1].
Most of the diseases affecting the thyroid gland e.g. goitre, thyrotoxicosis, adenoma, carcinoma etc. are usually associated with enlargement of gland and require medical and surgical intervention.

There are many variations in the shape, size and relative level of the thyroid gland. Therefore, knowledge of the variation in morphological and topographical anatomy is very important in 
evaluation and management of thyroid disorders in clinical practice.

\section{MATERIALS AND METHODS}

With the prior permission and approval of the Ethical Committee, one hundred apparently normal thyroid gland specimens were collected from human cadavers of known age and gender. In the present study, the thyroid gland specimens were obtained from 58 male and 42 female adult cadavers of 35 to 90 years age group.

The dissection was carried out and the thyroid glands were exposed. Before removal of thyroid gland, its position in relation to the tracheal rings was observed and noted.

After removal, the thyroid gland specimens were dried with the help of tissue papers. Electronic weighing machine was used to measure weight of the thyroid glands. Its measurements like height, width of each lobe and isthmus were measured with the help of vernier caliper.

The samples were divided into two groups according to gender into males and females. Statistical analysis was made to find out whether there any significant gender differences in the measurements of right and left lobe, isthmus and the weight of the gland.

The statistical analysis was done by applying Chi-square test and one sample test.

It was done by using SPSS and Minitab software.

Exclusion criteria: Cadavers having goitre and thyroidectomy were excluded.

\section{RESULTS}

The right lobe of the thyroid gland was found to be larger than the left lobe. An average length and width of isthmus were $1.38 \mathrm{~cm}$ and $1.02 \mathrm{~cm}$. An average weight of thyroid gland was 14.5grams. (Table no 1)

The length of right lobe was more in females. The width of right lobe in male and female was equal. The size of the right lobe was larger in females than males. The weight of thyroid gland was more in males than in females.

In the above data the $P$ value was 0.00 it shows that gender wise difference in different parameters was highly significant. (Table no 2)

Most commonly the isthmus was lying opposite to $1^{\text {st }} 2^{\text {nd }}$ and $3^{\text {rd }}$ tracheal rings.

In 28 cases the isthmus was absent and two lobes were lying separated.

$P$ value was 0.473 . It shows that gender wise difference in position of isthmus was statistically insignificant. (Table no 3 )

Table 1: Showing the minimum and maximum the parameters of the thyroid gland with its mean and standard deviation.

\begin{tabular}{|c|c|c|c|c|c|c|}
\hline Sr. no. & Parameters & $\mathbf{N}$ & Min. $(\mathrm{cm})$ & Max. $(\mathrm{cm})$ & Mean $(\mathrm{cm})$ & S.D. \\
\hline $\mathbf{1}$ & Length of Right lobe & 100 & 3 & 6.7 & 4.61 & 0.75525 \\
\hline $\mathbf{2}$ & Width of Right lobe & 100 & 0.8 & 3.6 & 2.383 & 0.53088 \\
\hline $\mathbf{3}$ & Length of Left lobe & 100 & 2.1 & 6.3 & 4.36 & 0.83182 \\
\hline $\mathbf{4}$ & Width of Left lobe & 100 & 0.7 & 3.5 & 2.231 & 0.56241 \\
\hline $\mathbf{5}$ & Length of Isthmus & 100 & 0.7 & 4.6 & 1.383 & 1.03729 \\
\hline $\mathbf{6}$ & Width of isthmus & 100 & 0.2 & 2.8 & 1.018 & 0.79498 \\
\hline $\mathbf{7}$ & $\begin{array}{c}\text { Weight of the thyroid } \\
\text { gland }\end{array}$ & 100 & 0.4 & 30 & 14.5 & 5.59758 \\
\hline
\end{tabular}

Table 2: Showing the gender difference in the parameters of the thyroid gland.

\begin{tabular}{|c|c|c|c|c|c|}
\hline Gender & Parameters & Min. cm. & Max. & Mean & S. D. \\
\hline \multirow{4}{*}{ Male 58 } & Length of Right lobe & 3 & 6.7 & 4.5741 & 0.75871 \\
\cline { 2 - 6 } & Width of Right lobe & 0.8 & 3.6 & 2.4586 & 0.49631 \\
\cline { 2 - 6 } & Length of Left lobe & 2.1 & 6.3 & 4.3155 & 0.80324 \\
\cline { 2 - 6 } & Width of Left lobe & 0.7 & 3.3 & 2.1931 & 0.58125 \\
\cline { 2 - 6 } & Length of Isthmus & 0.7 & 4.6 & 1.3241 & 1.15687 \\
\cline { 2 - 6 } & Width of isthmus & 0.2 & 2.8 & 0.9621 & 0.85877 \\
\cline { 2 - 6 } & Weight of thyroid gland & 0.4 & 30 & 14.948 & 5.60473 \\
\hline & Length of Right lobe & 3 & 6.2 & 4.6595 & 0.75678 \\
\cline { 2 - 6 } & Width of Right lobe & 1.1 & 3.5 & 2.2786 & 0.56462 \\
\cline { 2 - 6 } & Length of Left lobe & 2.4 & 6.3 & 4.4214 & 0.87584 \\
\cline { 2 - 6 } & Width of Left lobe & 1.2 & 3.5 & 2.2833 & 0.5378 \\
\cline { 2 - 6 } & Length of Isthmus & 0 & 3.2 & 1.4643 & 0.85192 \\
\cline { 2 - 6 } & Width of isthmus & 0 & 2.5 & 1.0952 & 0.70016 \\
\cline { 2 - 6 } & Weight of thyroid gland & 4.2 & 30 & 13.8857 & 5.59637 \\
\hline
\end{tabular}

\section{One sample test, $P$ value $\mathbf{= 0 . 0 0}$}

Table 3: Showing the position of the isthmus according to gender.

\begin{tabular}{|c|c|c|c|}
\hline $\begin{array}{c}\text { Position of the isthmus in } \\
\text { relation to cricoid cartilage } \\
\text { and tracheal rings }\end{array}$ & Male & Female & Total \\
\hline cricoid cart.,1,2 & 1 & 1 & 2 \\
\hline $\mathbf{2}$ & 1 & 3 & 4 \\
\hline $\mathbf{1 , 2}$ & 10 & 3 & 13 \\
\hline $\mathbf{1 , 2 , 3}$ & 11 & 6 & 17 \\
\hline $\mathbf{1 , 2 , 3 , 4}$ & 4 & 3 & 7 \\
\hline $\mathbf{1 , 2 , 3 , 4 , 5}$ & 1 & 0 & 1 \\
\hline $\mathbf{2 , 3}$ & 8 & 4 & 12 \\
\hline $\mathbf{2 , 3 , 4}$ & 7 & 3 & 10 \\
\hline $\mathbf{2 , 3 , 4 , 5}$ & 2 & 1 & 3 \\
\hline $\mathbf{3 , 4}$ & 1 & 1 & 2 \\
\hline $3,4,5$ & 1 & 0 & 1 \\
\hline Absent isthmus & 11 & 17 & 28 \\
\hline Total & $\mathbf{5 8}$ & $\mathbf{4 2}$ & $\mathbf{1 0 0}$ \\
\hline
\end{tabular}

Pearson Chi-Square value $=10.648$ and $P$ value $=0.473$ 
Shobha Gaikwad, Rajani Joshi. A MORPHOMETRIC STUDY OF THE THYROID GLAND IN HUMAN CADAVERS

Table 4: Comparison of various studies for Position of isthmus of thyroid gland With Present Study.

\begin{tabular}{|c|c|c|c|c|c|}
\hline Related structures & $\begin{array}{c}\text { Seheli Zannat } \\
\text { sultana[1] } 41 \\
\text { cases }\end{array}$ & $\begin{array}{c}\text { S.D. Joshi [5]75 } \\
\text { cases }\end{array}$ & $\begin{array}{l}\text { Enayetullah[11] } \\
50 \text { cases }\end{array}$ & $\begin{array}{l}\text { Begum }[10] \\
60 \text { cases }\end{array}$ & $\begin{array}{c}\text { present } \\
\text { study } 72 \\
\text { cases }\end{array}$ \\
\hline Cricoids, $1^{\text {st }}$ and $2^{\text {nd }}$ rings & - & $4 \%$ & - & - & $4.16 \%$ \\
\hline Only $1^{\text {st }}$ & - & $2.66 \%$ & - & - & $2.77 \%$ \\
\hline $1^{\text {st }}$ and $2^{\text {nd }}$ & $10 \%$ & $18.66 \%$ & - & - & $18.05 \%$ \\
\hline $1^{\text {st }}, 2^{\text {nd }}, 3^{\text {rd }}$ & $18.30 \%$ & $25.33 \%$ & - & - & $23.61 \%$ \\
\hline $1^{\text {st }}$ to $4^{\text {th }}$ & $1.70 \%$ & $5.33 \%$ & - & - & $9.72 \%$ \\
\hline $1^{\text {st }}$ to $5^{\text {th }}$ & $1.70 \%$ & - & - & - & $1.30 \%$ \\
\hline Only $2^{\text {nd }}$ & - & $4 \%$ & - & - & $5.55 \%$ \\
\hline $2^{\text {nd }}$ to $3^{\text {rd }}$ & $10.00 \%$ & $25.33 \%$ & - & - & $15.27 \%$ \\
\hline $2^{\text {nd }}$ to $4^{\text {th }}$ & $18.30 \%$ & $13.33 \%$ & $72 \%$ & $71.67 \%$ & $13.88 \%$ \\
\hline $2^{\text {nd }}$ to $5^{\text {th }}$ & - & $1.33 \%$ & - & $26.77 \%$ & $4.16 \%$ \\
\hline $3^{\text {rd }}$ to $5^{\text {th }}$ & - & - & - & - & $1.30 \%$ \\
\hline
\end{tabular}

\section{DISCUSSION}

The thyroid gland is having important functions of the body like maintains the rate of metabolism, blood calcium level, and affects the growth and development in mammals. The thyroid gland is notably a labile gland that varies greatly in size and structure [2].

Wood Jones [12] stated that the size and shape of the thyroid gland is subject to much variation.

Seeing the extreme variations in the gross anatomy of the gland, Marshall [13] stated that it was difficult to speak of a normal thyroid gland.

Hegedus et al [14] attributed the differences in thyroid gland volume between males and females to their body weight differences. This influence of body weight on the thyroid volume was about three times that of the age.

The workers in the radiology department usually gets exposed to the radiation while working, so to give full protection against the accompanying hazards, the standard weight, size, and shape of the thyroid should be known [9].

The results of present study are similar with the studies done previously. In the present study, the length and width of the right lobe of thyroid gland were found to be $4.61 \mathrm{cms}$ and $2.38 \mathrm{cms}$ respectively. These Findings were similar to the study done by Prakash et al [7] i.e. $4.43 \mathrm{~cm}$ and $2.54 \mathrm{~cm}$ respectively. Studies done by Harjeet et al [3] and S.D. joshi et al [5] also found similar length of right lobe i.e. $4.04 \mathrm{~cm}$ and $4.32 \mathrm{~cm}$ respectively. Daksha Dixit et al [4] found the length of right lobe of thyroid gland slightly more $(5.29 \mathrm{~cm})$ than the present study .

In the present study the length and width of left lobe of thyroid gland was $4.36 \mathrm{~cm}$ and $2.23 \mathrm{~cm}$ respectively. These were similar to the findings of Prakash et al [7] i.e. $4.21 \mathrm{~cm}$ and $2.63 \mathrm{~cm}$ respectively.

According to S.D. joshi et al [5] and Daksha Dixit et al [4] the length of left lobe was $4.22 \mathrm{~cm}$ and 4.95 respectively. These findings were similar to the findings of present study $(4.36 \mathrm{~cm})$. According to Harjeet et al [3] it was $3.82 \mathrm{~cm}$.

According to Rimpi Gupta et al [6] the length of right and left lobe of thyroid gland was $3.5 \mathrm{~cm}$ and $3 \mathrm{~cm}$ respectively and width was $2.2 \mathrm{~cm}$ and $2 \mathrm{~cm}$ respectively.

Sultana SZ et al [1] in their study found that Mean $\pm S D$ values for length and breadth of isthmus were $9.33 \pm 6.64 \mathrm{~mm}$ and $12.27 \pm 3.97 \mathrm{~mm}$ respectively. In the present study findings were $10.32 \pm 10.15 \mathrm{~mm}$ and $9.62 \pm 8.58 \mathrm{~mm}$ respectively.

According to S D Joshi [5] the mean height and width of isthmus were $1.1 \mathrm{~cm}$ and $1.85 \mathrm{~cm}$ respectively. In our study the findings were 1.38 $\mathrm{cm}$ and $1.018 \mathrm{~cm}$ respectively.

In the present study, the mean weight of the thyroid gland in case of males was found to be 14.94 grams and in case of females it was 13.89 grams. The weight was more in the study done by Tanriover 0 [9] i.e. $26.93 \mathrm{gm}$ and $21.93 \mathrm{gm}$ respectively. Tanriover o [9] has shown that the weight was more in males than females. Average weight of thyroid gland in the present 
study is $14.5 \mathrm{gm}$ and it was shown more in the study of Tanriover o [9] i. e. $26.11 \pm 8.14 \mathrm{gm}$. According to Nurunnabi ASM[2] and Harjeet A [3] the weight of thyroid gland in males was $14.64 \pm 2.07 \mathrm{gm}$. and $15.01 \pm 7.69 \mathrm{gm}$. respectively. Their findings were similar to the present study (14.94 gm).Whereas the findings of Pankow BG[11] was more (18.5gm) than the present study.

In case of females; the findings of Nurunnabi ASM [2], Harjeet et al [6] and Pankow BG et al [8] were $14.67 \pm 3.02 \mathrm{gm}, 13.16 \pm 5.64 \mathrm{gm}$, and 14.4 gm respectively. These findings were similar to the present study.

In the study done by Begum [10] and Enayetullah [11] the average weight of thyroid gland was $13.56 \pm 3.60 \mathrm{gm}$ and $14.35 \pm 5.86$ gm respectively.

In the present study 100 cases were studied out of that in 28 cases the isthmus was absent and in 72 cases isthmus was present. In 72 cases the posterior relation of isthmus has shown in table no 5.

In the present study the isthmus was lying opposite to $1^{\text {st }}, 2^{\text {nd }}, 3^{\text {rd }}$ tracheal rings most commonly. It was found in $23.61 \%$ of cases in the present study. These findings were similar to the study done by Seheli Zannat sultana [1] and S.D. Joshi [5] i.e. $18.3 \%$ and $25.33 \%$ respectively.

In the present study; least commonly the thyroid gland was situated opposite to the $1^{\text {st }}$ to $5^{\text {th }}$ tracheal rings $(1.3 \%)$ and it was similar to the findings of Seheli Zannat sultana [1] i.e. (1.7\%)

\section{CONCLUSION}

The study was carried out in 100 cadavers in Maharashtra region and it has shown that the size of right lobe of thyroid gland was more in females than males. The weight of thyroid gland was more in males. The gender wise difference in parameters was statistically highly significant.

Most commonly the isthmus was lying opposite to $1^{\text {st }}, 2^{\text {nd }}, 3^{\text {rd }}$ tracheal rings. The gender wise difference in position of isthmus was statistically insignificant. So, the knowledge about the morphometric and topographic anatomy of the thyroid gland is very important in the surgical treatment of different tumours and during tracheostomy.

\section{ABBREVIATIONS}

$\mathbf{N}$ - Number

Min.-Minimum

Max. - Maximum

S.D. - Standard deviation

\section{ACKNOWLEDGEMENTS}

Dr. Pritha Bhuiyan, Professor \& Head, Department of Anatomy, Seth G S Medical College , Mumbai for her kind support and encouragement.

\section{Conflicts of Interests: None}

\section{REFERENCES}

[1]. Seheli Zannat Sultana, Mohsin Khalil, Manjurul Karim Khan, Laila Anjuman Banu, Zubaida Gulshan Ara, Fakhrul Amin Mohammad Hasanul Banna. Incidence of Presence \& Variation in Anatomical Position of Isthmus of Thyroid Gland in Bangladeshi Cadaver.Bangladesh Journal of Anatomy January 2011;9(1):26-29.

[2]. Nurunnabi ASM, Alim A, M Sabiha, B Manowara, K Monira, A Shamim. Weight of the Human Thyroid Gland - A Postmortem Study; Bangladesh Journal of Medical Science 2010;09(1).

[3]. Harjeet A, Sahni D, Jit I, Aggarwal AK.; Shape, measurements and weight of the thyroid gland in northwest Indians; Surg Radiol Anat. 2004 Apr;26(2):915.

[4]. Daksha Dixit, MB Shilpa, MP Harsh, and MV Ravishankar. Agenesis of isthmus of thyroid gland in adult human cadavers: a case series; Cases J. 2009;2:6640.

[5]. S.D. Joshi, S.S. Joshi, S.R. Daimi, S.A. Athavale. The thyroid gland and its variations:a cadaveric study.Folia Morphol., 2010;69(1).

[6]. Rimpi gupta, Rajan kumar singla; Multiple Anomalies in the Morphology and the Blood Supply of the Thyroid Gland: A Case Report ; Journal of Clinical and Diagnostic Research. 2011;5(8):1634-1636.

[7]. Prakash, Thimmiah Rajini, Archana Ramachandran et.al. Variations in the anatomy of the thyroid gland: clinical implications of a cadaver study; Anat Sci Int 2012;87:45-49. DOI 10.1007/s12565-011-01159.

[8]. Pankow BG, Michalak J, McGee MK., Adult human thyroid weight, Health Phys. 1985 Dec;49(6):1097103.

[9]. Tanriover O, Comunoglu N, Eren B, Comunoglu C, Turkmen N, Bilgen S, Kaspar EC, Gündogmus UN. ; Morphometric features of the thyroid gland: a cadaveric study of Turkish people; Folia Morphol (Warsz). 2011 May;70(2):103-8. 
[10]. M Begum, M Khatun, S Kishwara, R Ahmed, J Naushaba. A Postmortem Study of the Pyramidal lobe of the Thyroid Gland in Bangladeshi People. Journal of Dhaka Medical College 2009;18(2).

[11]. Enaytullah M.Gross and histomorphological study of the thyroid gland and parathyroid glands in Bangladeshi peoples (M.Phil.thesis). Dhaka: University of Dhaka;1996.

[12]. Wood JF (1953) Buchanan's manual of anatomy. 8th Ed. Billiere Tendall and Cox, London
[13]. Marshall CF. Variations in the form of the thyroid gland in man. J Anat, 1895;29:234-339.

[14]. Hegedus L, Perrild H, Poulsen LR, Jesper R, Andersen M, Holm B, Schnohr P, Jensen G, Hansen JM. The determination of thyroid volume by ultrasound and its relationship to body weight, age and sex in normal subjects. J Clin Endocrinol Metabol, 1983;56:260-263.

How to cite this article:

Shobha Gaikwad, Rajani Joshi. A MORPHOMETRIC STUDY OF THE THYROID GLAND IN HUMAN CADAVERS. Int J Anat Res 2018;6(4.1):5783-5787. DOI: 10.16965/ijar.2018.341 